\title{
An Unusual Exchange between Alkylidyne Alkyl and Bis(alkylidene) Tungsten Complexes Promoted by Phosphine Coordination: Kinetic, Thermodynamic and Theoretical Studies
}

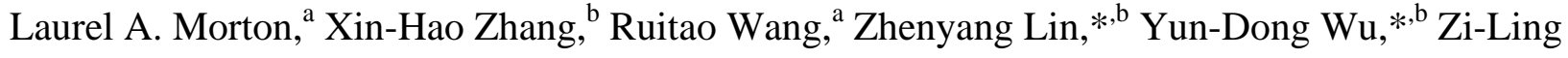 \\ $\mathrm{Xue}^{*, \mathrm{a}}$ \\ ${ }^{a}$ Department of Chemistry, The University of Tennessee, Knoxville, Tennessee 37996, \\ ${ }^{b}$ Department of Chemistry, Hong Kong University of Science and Technology, Hong Kong, \\ China
}

Supporting Information 


\section{Experimental Section}

All manipulations were performed under a dry nitrogen atmosphere with the use of either a drybox or standard Schlenk techniques. All solvents were purified by distillation from potassium/benzophenone ketyl. Toluene- $d_{8}$ and benzene- $d_{6}$ were dried over activated molecular sieves and stored under $\mathrm{N}_{2}$. NMR spectra were recorded on a Bruker AMX-400 or a Bruker AC Fourier transform spectrometer.

Preparation and characterization of $\left(\mathrm{Me}_{3} \mathrm{SiCH}_{2}\right)_{3} \mathbf{W} \equiv \mathrm{CSiMe}_{3}(5 \mathrm{a}) . \quad\left(\mathrm{Me}_{3} \mathrm{SiCH}_{2}\right)_{3} \mathrm{~W} \equiv \mathrm{CSiMe}$ (5a) was prepared by a procedure different from that in the literature. ${ }^{31} \mathrm{~W}\left(\mathrm{CH}_{3} \mathrm{O}\right)_{3} \mathrm{Cl}_{3}$ crystals $(5.74 \mathrm{~g})^{\mathrm{S} 1}$ in $\mathrm{Et}_{2} \mathrm{O}$ were added dropwise to 6 equiv of $1 \mathrm{M} \mathrm{Me}_{3} \mathrm{SiCH}_{2} \mathrm{MgCl}$ in $\mathrm{Et}_{2} \mathrm{O}$ at $-5^{\circ} \mathrm{C}$. The mixture was then slowly warmed to room temperature overnight with stirring. It was filtered, and the solid was extracted with $\mathrm{Et}_{2} \mathrm{O}$. The volatiles in the extract were removed, and the oily product was pumped at $40{ }^{\circ} \mathrm{C}$ for $4 \mathrm{~h}$. Pentane was then added, and the solution was filtered. Pentane was removed in vacuo, and the oily product was pumped at $40{ }^{\circ} \mathrm{C}$ for $4 \mathrm{~h}$. Sublimation at $50-60{ }^{\circ} \mathrm{C}$ yielded yellow crystals $\left(3.31 \mathrm{~g}, 41.6 \%\right.$ yield based on $\left.\mathrm{W}(\mathrm{OMe})_{3} \mathrm{Cl}_{3}\right) .{ }^{1} \mathrm{H} \mathrm{NMR}$ (toluene- $\left.d_{8}, 400.11 \mathrm{MHz}, 23{ }^{\circ} \mathrm{C}\right) \delta 0.688\left(\mathrm{~s}, 6 \mathrm{H}, \mathrm{CH}_{2} \mathrm{SiMe}_{3}\right.$ ), 0.428 (s, 9H, $\equiv \mathrm{CSiMe}$ ), 0.173 (s, 27H, $\mathrm{CH}_{2} \mathrm{SiMe}_{3}$ ). ${ }^{1} \mathrm{H}$ NMR (toluene- $d_{8}, 400.11 \mathrm{MHz},-50{ }^{\circ} \mathrm{C}$ ) $\delta 0.671\left(\mathrm{~s}, 6 \mathrm{H}, \mathrm{CH}_{2} \mathrm{SiMe}_{3}\right.$ ), 0.489 $\left(\mathrm{s}, 9 \mathrm{H}, \equiv \mathrm{CSi} M e_{3}\right), 0.207\left(\mathrm{~s}, 27 \mathrm{H}, \mathrm{CH}_{2} \mathrm{SiMe}_{3}\right) .{ }^{13} \mathrm{C} \mathrm{NMR}$ (toluene- $d_{8}, 100.63 \mathrm{MHz}, 0{ }^{\circ} \mathrm{C}, \mathrm{J}$ in $\mathrm{Hz}$ ) $\delta$ $343.27\left(\equiv \mathrm{CSiMe}_{3}\right), 75.72\left(\mathrm{CH}_{2} \mathrm{SiMe}_{3},{ }^{1} \mathrm{~J}_{\mathrm{C}-\mathrm{H}}=111.2,{ }^{1} \mathrm{~J}_{\mathrm{W}-\mathrm{C}}=78.5\right), 2.75\left(\mathrm{CH}_{2} \mathrm{SiMe}_{3},{ }^{1} \mathrm{~J}_{\mathrm{C}-\mathrm{H}}=\right.$ 118.1), $2.64\left(\equiv \mathrm{CSiMe}_{3},{ }^{1} \mathrm{~J}_{\mathrm{C}-\mathrm{H}}=119.1\right)$.

Preparation of $\left(\mathrm{Me}_{3} \mathrm{SiCH}_{2}\right)_{3} \mathbf{W}\left(\equiv \mathrm{CSiMe}_{3}\right)\left(\mathrm{PMe}_{3}\right)(4 \mathrm{a})$. 4a was prepared by the vacuum transfer of $\mathrm{PMe}_{3}(25 \mathrm{mmHg}, 0.104 \mathrm{mmol})$ to a J. R. Young's NMR tube containing 5a (48 mg, 0.0904 $\mathrm{mmol}$ ) in toluene- $d_{8}$. The reaction mixture is kept frozen in liquid nitrogen until placed in the precooled NMR probe at $-50{ }^{\circ} \mathrm{C}$. 4a: ${ }^{1} \mathrm{H}$ NMR (toluene- $d_{8}, 400.11 \mathrm{MHz},-50{ }^{\circ} \mathrm{C}, \mathrm{J}$ in $\mathrm{Hz}$ ) $\delta 0.904$ (d, $\left.9 \mathrm{H}, \mathrm{PMe}_{3},{ }^{2} J_{\mathrm{P}-\mathrm{H}}=7.2\right), 0.751\left(\mathrm{dd}, 2 \mathrm{H}\right.$, eq- $\left.\mathrm{CH}_{a} \mathrm{H}_{\mathrm{b}}-\mathrm{SiMe}_{3},{ }^{2} J_{\mathrm{H}-\mathrm{H}}={ }^{3} J_{\mathrm{P}-\mathrm{H}}=14.4\right), 0.503(\mathrm{~s}, 9 \mathrm{H}$, $\left.\equiv \mathrm{CSiMe})_{3}\right), 0.487$ (d, 2H, ax $\left.-\mathrm{CH}_{2} \mathrm{SiMe}_{3},{ }^{3} \mathrm{~J}_{\mathrm{P}-\mathrm{H}}=10.7\right), 0.329\left(\mathrm{~s}, 9 \mathrm{H}, \mathrm{ax}-\mathrm{CH}_{2} \mathrm{SiMe}\right.$ ), $0.316(\mathrm{~s}, 18 \mathrm{H}$, 
eq- $\mathrm{CH}_{2} \mathrm{SiMe}$ ), $0.213\left(\mathrm{dd}, 2 \mathrm{H}\right.$, eq- $\left.\mathrm{CH}_{a} H_{b}-\mathrm{SiMe}_{3},{ }^{3} \mathrm{~J}_{\mathrm{P}-\mathrm{H}}=28.2,{ }^{2} J_{\mathrm{H}-\mathrm{H}}=14.1\right) ;{ }^{13} \mathrm{C}\left\{{ }^{1} \mathrm{H}\right\} \mathrm{NMR}$ (toluene- $d_{8}, 100.63 \mathrm{MHz},-50{ }^{\circ} \mathrm{C}, J$ in Hz) $\delta 358.81$ (d, $\equiv \mathrm{CSiMe}_{3},{ }^{2} J_{\mathrm{P}-\mathrm{C}}=14.5,{ }^{1} J_{\mathrm{W}-\mathrm{C}}=159.1$ ), $81.69\left(\mathrm{~d}, \mathrm{ax}-\mathrm{CH}_{2} \mathrm{SiMe}_{3},{ }^{2} J_{\mathrm{P}-\mathrm{C}}=36.5,{ }^{1} J_{\mathrm{W}-\mathrm{C}}=117.9\right), 49.45\left(\mathrm{~d}\right.$, eq- $\mathrm{CH}_{2} \mathrm{SiMe}_{3},{ }^{1} J_{\mathrm{H}-\mathrm{C}}=111.6,{ }^{2} J_{\mathrm{P}-\mathrm{C}}=$ $\left.7.2,{ }^{1} J_{\mathrm{W}-\mathrm{C}}=59.9\right), 17.84\left(\mathrm{~d}, \mathrm{PMe}_{3},{ }^{1} \mathrm{~J}_{\mathrm{H}-\mathrm{C}}=128.2,{ }^{1} \mathrm{~J}_{\mathrm{P}-\mathrm{C}}=22.8\right), 4.23\left(\mathrm{~s}, \equiv \mathrm{CSiMe},{ }^{1} \mathrm{~J}_{\mathrm{H}-\mathrm{C}}=117.8\right.$, $\left.{ }^{3} J_{\mathrm{W}-\mathrm{C}}=50.1\right), 3.55\left(\mathrm{~s}, \mathrm{ax}-\mathrm{CH}_{2} \mathrm{SiMe}_{3},{ }^{1} \mathrm{~J}_{\mathrm{H}-\mathrm{C}}=117.1,{ }^{3} \mathrm{~J}_{\mathrm{W}-\mathrm{C}}=33.2\right), 3.48\left(\mathrm{~s}\right.$, eq- $\mathrm{CH}_{2} \mathrm{SiMe}_{3},{ }^{1} \mathrm{~J}_{\mathrm{H}-\mathrm{C}}=$ 117.1, $\left.{ }^{3} J_{W-C}=25.0\right) ;{ }^{31} \mathrm{P}\left\{{ }^{1} \mathrm{H}\right\}\left(\right.$ toluene- $d_{8}, 161.97 \mathrm{MHz},-50{ }^{\circ} \mathrm{C}, \mathrm{J}$ in $\left.\mathrm{Hz}\right) \delta-5.64\left(\mathrm{~s},{ }^{1} J_{W-P}=28.9\right)$; ${ }^{29} \mathrm{Si}\left\{{ }^{1} \mathrm{H}\right\}$ (toluene- $d_{8}, 79.49 \mathrm{MHz},-50{ }^{\circ} \mathrm{C}, \mathrm{J}$ in $\left.\mathrm{Hz}\right) \delta-0.269\left(\mathrm{~d}, \mathrm{ax}-\mathrm{CH}_{2} \mathrm{SiMe}_{3},{ }^{3} \mathrm{~J}_{\mathrm{P}-\mathrm{Si}}=2.0\right.$ ), -2.482 $\left(\mathrm{d}\right.$, eq-CH $\left.\mathrm{CH}_{2} \mathrm{SiMe}_{3},{ }^{3} \mathrm{~J}_{\mathrm{P}-\mathrm{Si}}=4.9,{ }^{2} J_{\mathrm{W}-\mathrm{Si}}=50.2\right),-21.129\left(\mathrm{~d}, \equiv \mathrm{CSiMe},{ }^{3} J_{\mathrm{P}-\mathrm{Si}}=2.3,{ }^{2} J_{\mathrm{W}-\mathrm{Si}}=52.3\right)$. The assignments of the ${ }^{1} \mathrm{H}$ and ${ }^{13} \mathrm{C}$ NMR were confirmed by low-temperature $\mathrm{HMQC}$ experiments. Upon warming the solution to room temperature, $\mathbf{4 a}$ was found to convert to $\mathbf{4 b}$ via an $\alpha-\mathrm{H}$ migration reaction.

Preparation of $\left(\mathrm{Me}_{3} \mathrm{SiCH}_{2}\right)_{2} \mathbf{W}\left(=\mathrm{CHSiMe}_{3}\right)_{2}\left(\mathrm{PMe}_{3}\right)$ (4b). A solution of $\left(\mathrm{Me}_{3} \mathrm{SiCH}_{2}\right)_{3} \mathrm{~W} \equiv \mathrm{CSiMe}_{3}$ (5a, $95 \mathrm{mg}, 0.179 \mathrm{mmol})$ in pentane was frozen by liquid nitrogen in a 125-ml Schlenk flask. The flask headspace was evacuated. $\mathrm{PMe}_{3}(100 \mathrm{mmHg}, 0.358 \mathrm{mmol})$ was then vacuum transferred to the flask submerged in liquid nitrogen. The $\mathrm{PMe}_{3}$ was then condensed in the flask, and the flask was warmed to room temperature. The flask was then added nitrogen, and stirred overnight at room temperature. Cooling the solution at $-30^{\circ} \mathrm{C}$ overnight gave crystals of 4b (87 mg, $0.143 \mathrm{mmol}, 80 \%$ yield). ${ }^{1} \mathrm{H}$ NMR (toluene- $d_{8}, 400.11 \mathrm{MHz},-20{ }^{\circ} \mathrm{C}, \mathrm{J}$ in $\mathrm{Hz}$ ) $\delta 7.985$ $\left(\mathrm{d}, 1 \mathrm{H},=\mathrm{CHSiMe},{ }^{3} J_{\mathrm{P}-\mathrm{H}}=5.6\right), 7.192\left(\mathrm{~d}, 1 \mathrm{H},=\mathrm{CHSiMe}_{3},{ }^{3} J_{\mathrm{P}-\mathrm{H}}=4.0\right), 1.024\left(\mathrm{~d}, 9 \mathrm{H}, \mathrm{PMe}_{3},{ }^{2} J_{\mathrm{P}-\mathrm{H}}=\right.$ 7.8), $0.917\left(\mathrm{dd}, 1 \mathrm{H}\right.$, eq- $\left.\mathrm{CH}_{\mathrm{a}} \mathrm{H}_{\mathrm{b}}-\mathrm{SiMe}_{3},{ }^{3} \mathrm{~J}_{\mathrm{P}-\mathrm{H}}=17.7,{ }^{2} \mathrm{~J}_{\mathrm{H}-\mathrm{H}}=11.3\right), 0.876$ (dd, $1 \mathrm{H}$, eq- $\mathrm{CH}_{\mathrm{a}} \mathrm{H}_{\mathrm{b}}-\mathrm{SiMe}_{3}$, ${ }^{3} J_{\mathrm{P}-\mathrm{H}}=32.2,{ }^{2} \mathrm{~J}_{\mathrm{H}-\mathrm{H}}=11.3$; overlapped with eq- $\mathrm{CH}_{\mathrm{a}} \mathrm{H}_{\mathrm{b}}-\mathrm{SiMe}_{3}$ peak), $0.388\left(\mathrm{~s}, 9 \mathrm{H}\right.$, ax $-\mathrm{CH}_{2} \mathrm{SiMe}_{3}$, $\left.{ }^{2} J_{\mathrm{Si}-\mathrm{H}}=6.0\right), 0.388\left(\mathrm{~d}, 2 \mathrm{H}, \mathrm{ax}-\mathrm{CH}_{2} \mathrm{SiMe}_{3},{ }^{3} \mathrm{~J}_{\mathrm{P}-\mathrm{H}}=11.4\right.$; overlapped with $\mathrm{ax}-\mathrm{CH}_{2} \mathrm{SiMe} 3$ peak), 0.342 (s, 9H, eq- $\mathrm{CH}_{2} \mathrm{SiMe}_{3}$ ), 0.280 (s, 9H, =CHSiMe $\left.)_{3}\right), 0.128$ (s, 9H, =CHSiMe $\left.e_{3}\right) ;{ }^{13} \mathrm{C}\left\{{ }^{1} \mathrm{H}\right\}$ (toluene- $d_{8}$, 100.63 MHz, $-40{ }^{\circ} \mathrm{C}, J$ in Hz) $\delta 256.43\left(\mathrm{~d},=\mathrm{CHSiMe}_{3},{ }^{1} J_{\mathrm{H}-\mathrm{C}}=123.5,{ }^{2} J_{\mathrm{P}-\mathrm{C}}=11.8\right), 254.71(\mathrm{~d}$, $\left.=\mathrm{CHSiMe},{ }^{1} J_{\mathrm{H}-\mathrm{C}}=102.6,{ }^{2} J_{\mathrm{P}-\mathrm{C}}=12.6\right), 50.71\left(\mathrm{~s}\right.$, eq $\left.-\mathrm{CH}_{2} \mathrm{SiMe}_{3},{ }^{1} J_{\mathrm{H}-\mathrm{C}}=105.3,{ }^{1} J_{\mathrm{W}-\mathrm{C}}=43.0\right), 38.01$ 
$\left(\mathrm{d}, \mathrm{ax}-\mathrm{CH}_{2} \mathrm{SiMe}_{3},{ }^{1} \mathrm{~J}_{\mathrm{H}-\mathrm{C}}=111.0,{ }^{2} \mathrm{~J}_{\mathrm{P}-\mathrm{C}}=32.3\right), 18.80\left(\mathrm{~d}, \mathrm{PMe},{ }^{1} \mathrm{~J}_{\mathrm{H}-\mathrm{C}}=126.4,{ }^{1} \mathrm{~J}_{\mathrm{P}-\mathrm{C}}=26.4\right), 4.82$

(s, ax- $\left.\mathrm{CH}_{2} \mathrm{SiMe}_{3},{ }^{1} \mathrm{~J}_{\mathrm{H}-\mathrm{C}}=118.1\right), 3.08\left(\mathrm{~s}, \mathrm{eq}-\mathrm{CH}_{2} \mathrm{SiMe}_{3},{ }^{1} \mathrm{~J}_{\mathrm{H}-\mathrm{C}}=118.8\right), 1.76\left(\mathrm{~s},=\mathrm{CHSiMe},{ }^{1} \mathrm{~J}_{\mathrm{H}-\mathrm{C}}\right.$ $=117.3), 1.64\left(\mathrm{~s},=\mathrm{CHSi} M e_{3},{ }^{1} \mathrm{~J}_{\mathrm{H}-\mathrm{C}}=117.3\right) ;{ }^{31} \mathrm{P}\left\{{ }^{1} \mathrm{H}\right\}$ (toluene- $d_{8}, 161.97 \mathrm{MHz},-50{ }^{\circ} \mathrm{C}, \mathrm{J}$ in Hz) $\delta$

$0.61\left(\mathrm{~s},{ }^{1} \mathrm{~J}_{\mathrm{W}-\mathrm{P}}=115.5\right) ;{ }^{29} \mathrm{Si}\left\{{ }^{1} \mathrm{H}\right\}$ (toluene- $d_{8}, 79.49 \mathrm{MHz},-50{ }^{\circ} \mathrm{C}, \mathrm{J}$ in $\left.\mathrm{Hz}\right) \delta-0.73(\mathrm{~d}, \mathrm{ax}-$

$\left.\mathrm{CH}_{2} \mathrm{SiMe}_{3},{ }^{3} \mathrm{~J}_{\mathrm{P}-\mathrm{Si}}=19.2\right),-1.96\left(\mathrm{~d}, \mathrm{eq}-\mathrm{CH}_{2} \mathrm{SiMe}_{3},{ }^{3} \mathrm{~J}_{\mathrm{P}-\mathrm{Si}}=4.1\right),-8.63\left(\mathrm{~d},=\mathrm{CHSiMe},{ }^{3} J_{\mathrm{P}-\mathrm{Si}}=2.9\right)$,

$-9.89\left(\mathrm{~d},=\mathrm{CHSiMe},{ }_{3}^{3} \mathrm{~J}_{\mathrm{P}-\mathrm{Si}}=4.8\right) .{ }^{1} \mathrm{H}$ and ${ }^{13} \mathrm{C}$ assignments were confirmed by low-temperature HMQC experiments. Anal. Calcd. C, 37.61, H, 8.47. Found C, 37.43, H, 8.66.

Kinetic studies of the reversible reactions $\left(\mathrm{Me}_{3} \mathrm{SiCH}_{2}\right)_{3} \mathrm{~W}\left(\equiv \mathrm{CSiMe}_{3}\right)\left(\mathrm{PMe}_{3}\right)(4 \mathrm{a}) \rightleftharpoons$

$\left(\mathrm{Me}_{3} \mathrm{SiCH}_{2}\right)_{2} \mathrm{~W}(=\mathrm{CHSiMe})_{2}\left(\mathrm{PMe}_{3}\right)$ (4b). At least two experiments for each temperature were conducted. A mixture of $\left(\mathrm{Me}_{3} \mathrm{SiCH}_{2}\right)_{3} \mathrm{~W} \equiv \mathrm{CSiMe}_{3}(\mathbf{5 a}), 4,4$ '-dimethylbiphenyl (an internal standard), and toluene- $d_{8}$ in J. R. Young's NMR tubes in liquid nitrogen were added ca. 2-21 equiv of $\mathrm{PMe}_{3}$ through vacuum transfer. The samples were kept below $-78{ }^{\circ} \mathrm{C}$ before insertion into the NMR probe. The NMR probe was pre-cooled or pre-heated to the set temperature. After the NMR tubes were into the probe, the ${ }^{1} \mathrm{H}$ NMR spectra were taken after the temperature was stabilized, and the integrations of $\mathbf{4 b}$, relative to those of the internal standard, were used as $I_{3 \mathbf{b}-0}$ at $t=0$. Once the equilibrium between $\mathbf{4 a}$ and $\mathbf{4 b}$ was reached, the integration of $\mathbf{4 b}$ was used as $I_{3 \mathrm{~b}-\mathrm{e}}$.

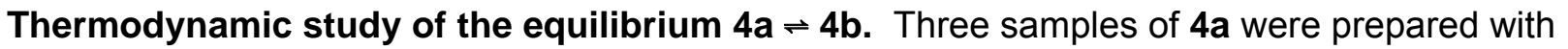
at least 10 equiv of $\mathrm{PMe}_{3}$, and kept at room temperature for over 24 hours to ensure equilibrium was established. The samples were then placed in a circulation bath at 278.0(0.1), 283.0(0.1), 288.0(0.1), 293.0(0.1), 298.0(0.1), or 303.0(0.1) $\mathrm{K}$ for at least 6 hours. ${ }^{31} \mathrm{P}$ NMR spectra were taken at $-50{ }^{\circ} \mathrm{C}$ with a relaxation delay of $10 \mathrm{~s} . K_{\text {eq }}=[4 \mathrm{~b}] /[4 \mathrm{a}]=I_{\mathbf{4 b}} / I_{\mathbf{4 a}}$ were calculated from the integrations of the two tautomers.

Reaction of $\left(\mathrm{Bu}^{\mathrm{t}} \mathrm{CH}_{2}\right)_{3} \mathrm{~W} \equiv \mathrm{CBu}^{\mathrm{t}}(1)$ with $\mathrm{PMe}_{3}$ at room temperature in benzene- $d_{6}$. Schrock and Clark have reported that the reaction of 1 with neat $\mathrm{PMe}_{3}$ in a sealed tube at $100{ }^{\circ} \mathrm{C}$ gave 
$\left(\mathrm{Bu}^{\mathrm{t}} \mathrm{CH}_{2}\right) \mathrm{W}\left(\equiv \mathrm{C}^{\mathrm{t}} \mathrm{Bu}\right)\left(=\mathrm{CH}^{\mathrm{t}} \mathrm{Bu}\right)\left(\mathrm{PMe}_{3}\right)_{2}(6) \cdot{ }^{3 \mathrm{j}}$ The current studies were conducted at room temperature in a solution to see if an adduct formed between 1 and $\mathrm{PMe}_{3 .} 1(100 \mathrm{mg}, 0.214$ $\mathrm{mmol}$ ) in benzene- $d_{6}$ in a J. R. Young's NMR tube in liquid nitrogen was added ca. 1 equiv of $\mathrm{PMe}_{3}$ through vacuum transfer. A slow reaction at room temperature occurred to give 6 . After 3 days $23^{\circ} \mathrm{C}$, a mixture of unreacted 1 (and $\mathrm{PMe}_{3}$ ) and 6 in ca. 1:2 ratio was observed. No adduct between 1 and $\mathrm{PMe}_{3}$ in the mixture was observed.

Calculations of $\boldsymbol{K}_{\mathrm{eq}}$ and error analysis. For the thermodynamic studies, the equilibrium constants $K_{\text {eq }}$ were obtained from at least two separate experiments at a given temperature, and their averages are listed in Table 1.

The largest random uncertainty is $\sigma K_{\text {eq(ran) }} / K_{\text {eq }}=0.2 / 12.3=1.6 \%$ (Table 1$)$. The total uncertainty $\sigma K_{\text {eq }} / K_{\text {eq }}$ of $5.2 \%$ was calculated from $\sigma K_{\text {eq(ran })} / K_{\text {eq }}=1.6 \%$ and the estimated systematic uncertainty $\sigma K_{\text {eq(sys }} / K_{\text {eq }}=5 \%$ by $\sigma K_{\text {eq }} / K_{\text {eq }}=\left[\left(\sigma K_{\text {eq(ran })} / K_{\text {eq }}\right)^{2}+\left(\sigma K_{\text {eq(sys) }} / K_{\text {eq }}\right)^{2}\right]^{1 / 2}$.

The maximum random uncertainty in the equilibrium constants was combined with the estimated systematic uncertainty, ca. $5 \%$. The total uncertainties in the equilibrium constants were used in the In $K_{\text {eq }}$ vs. 1/T plot and error propagation calculations. The estimated uncertainty in the temperature measurements for an NMR probe was $1 \mathrm{~K}$. The enthalpy $\left(\Delta H^{\circ}\right)$ and entropy $\left(\Delta S^{\circ}\right)$ changes were calculated from an unweighted nonlinear least-squares procedure contained in the SigmaPlot Scientific Graph System. The uncertainties in $\Delta H^{\circ}$ and $\Delta S^{\circ}$ were computed from the following error propagation formulas, which were derived from $-R T$ $\ln K_{\mathrm{eq}}=\Delta H^{\circ}-T \Delta S^{0.5 a}$

$$
\begin{aligned}
& \left(\sigma \Delta S^{\circ}\right)^{2}=2 R^{2} T_{\min }{ }^{2} T_{\max }{ }^{2}\left[\ln \left(K_{\text {eq }(\max )} / K_{\text {eq (min })}\right)\right]^{2}(\sigma T / T)^{2} / \Delta T^{4}+R^{2}\left(T_{\max }{ }^{2}+T_{\min }^{2}\right)\left(\sigma K_{\text {eq }} / K_{\text {eq }}\right)^{2} / \Delta T^{2} \\
& \left(\sigma \Delta H^{\circ}\right)^{2}=(\sigma T / T)^{2} R^{2}\left(T_{\max }{ }^{2} T_{\min }{ }^{4}+T_{\min }{ }^{2} T_{\max }{ }^{4}\right)\left[\ln \left(K_{\text {eq }(\max )} / K_{\text {eq }(\min )}\right)\right]^{2} / \Delta T^{4}+ \\
& 2 R^{2} T_{\max }{ }^{2} T_{\min }{ }^{2}\left(\sigma K_{\text {eq }} / K_{\text {eq }}\right)^{2} / \Delta T^{2}, \quad \text { where } \Delta T=\left(T_{\max }-T_{\min }\right) .
\end{aligned}
$$


Calculations of $\boldsymbol{k}_{1}$ and $\boldsymbol{k}_{-1}$ and Error Analysis. The rate constants were obtained from at least two independent experiments at a given temperature. The rate constants in Table 1 are the averages of the two experiments. The largest random uncertainties are $\delta k_{1(\mathrm{ran})} / k_{1}=0.13 / 2.47=$ $5.3 \%$ and $\delta k_{-1(\text { ran })} / k_{-1}=0.11 / 2.14=5.1 \%($ Table 1$)$. The total uncertainties $\delta k_{1} / k_{1}=0.0726$ and $\delta k_{-1} / k_{-1}=0.0717$ were calculated from $\delta k_{(\text {ran })} / k$ and the estimated systematic uncertainty $\delta k_{(\text {sys })} / k$ $=5 \%$ by $\delta k / k=\left[\left(\delta k_{(\text {ran })} / k\right)^{2}+\left(\delta k_{(\text {sys })} / k\right)^{2}\right]^{1 / 2}$.

The maximum random uncertainty in the rate constants for each reaction was combined with the estimated systematic uncertainties in the rate constants of ca. $5 \%$. The total uncertainties in the rate constants were used in the Eyring plots and in the following error propagation calculations. The estimated uncertainties in the temperature measurements for a circulation bath (used for $k_{-1}$ determinations) and for an NMR probe (used in the $k_{1}$ determinations) were $0.1 \mathrm{~K}$ and $1 \mathrm{~K}$, respectively. The activation enthalpies $\left(\Delta H^{\ddagger}\right)$ and entropies $\left(\Delta S^{\neq}\right)$were calculated from an unweighted non-linear least-squares procedure contained in the SigmaPlot Scientific Graph System. The uncertainties in $\Delta H^{\neq}$and $\Delta S^{\neq}$were computed from the error propagation formulas derived from Eyring equation by Girolami and coworkers. ${ }^{\text {S2 }}$ Computational details. All calculations were performed using the Gaussian 03 package ${ }^{\mathrm{S3}}$ with density functional theory at the B3LYP level. Full geometry optimizations were carried out with basis set I (BSI): LanL2DZ with f polarization functions for $\mathrm{W}^{\mathrm{S4}}$ and $6-31 \mathrm{G}^{*}$ for the rest of elements. Single point energies were calculated with basis set II (BSII): SDDAll for $\mathrm{W}^{\mathrm{S5}}$ and 6$311++G^{* *}$ for other elements. Vibration frequency calculations were performed for all the structures with the BSI. The calculated relative energies shown in the text have been corrected with zero-point-energy (ZPE). 


\section{Additional References}

S1. Schrock, R. R.; Sancho, J.; Pederson, S. F. Inorg. Synth. 1989, 26, 44.

S2. Morse, P. M.; Spencer, M. D.; Wilson, S. R.; Girolami, G. S. Organometallics 1994, 13, 1646.

S3. Frisch, M. J.; Trucks, G. W.; Schlegel, H. B.; Scuseria, G. E.; Robb, M. A.; Cheeseman, J. R.; Montgomery, J. A.; Vreven, Jr., T.; Kudin, K. N.; Burant, J. C.; Millam, J. M.; Iyengar, S. S.; Tomasi, J.; Barone, V.; Mennucci, B.; Cossi, M.; Scalmani, G.; Rega, N.; Petersson, G. A.; Nakatsuji, H.; Hada, M.; Ehara, M.; Toyota, K.; Fukuda, R.; Hasegawa, J.; Ishida, M.; Nakajima, T.; Honda, Y.; Kitao, O.; Nakai, H.; Klene, M.; Li, X.; Knox, J. E.; Hratchian, H. P.; Cross, J. B.; Adamo, C.; Jaramillo, J.; Gomperts, R.; Stratmann, R. E.; Yazyev, O.; Austin, A. J.; Cammi, R.; Pomelli, C.; Ochterski, J. W.; Ayala, P. Y.; Morokuma, K.; Voth, G. A.; Salvador, P.; Dannenberg, J. J.; Zakrzewski, V. G.; Dapprich, S.; Daniels, A. D.; Strain, M. C.; Farkas, O.; Malick, D. K.; Rabuck, A. D.; Raghavachari, K.; Foresman, J. B.; Ortiz, J. V.; Cui, Q.; Baboul, A. G.; Clifford, S.; Cioslowski, J.;

Stefanov, B. B.; Liu, G.; Liashenko, A.; Piskorz, P.; Komaromi, I.; Martin, R. L.; Fox, D. J.; Keith, T.; Al-Laham, M. A.; Peng, C. Y.; Nanayakkara, A.; Challacombe, M.; Gill, P. M. W.; Johnson, B.; Chen, W.; Wong, M. W.; Gonzalez, C.; Pople, J. A. Gaussian 03, Revision B.03, Gaussian, Inc., Pittsburgh PA, 2003.

S4. (a) Hay, P. J.; Wadt, W. R. J. Chem. Phys. 1985, 82, 299. (b) Ehlers, A. W.; Böhme, M.; Dapprich, S.; Gobbi, A.; Höllwarth, A.; Jonas, V.; Köhler, K. F.; Stegmann, R.; Veldkamp, A.; Frenking, G. Chem. Phys. Lett. 1993, 208, 111.

S5. Andrae, D.; Haeussermann, U.; Dolg, M.; Stoll, H.; Preuss, H. Theor. Chim. Acta 1990, 77, 123. 

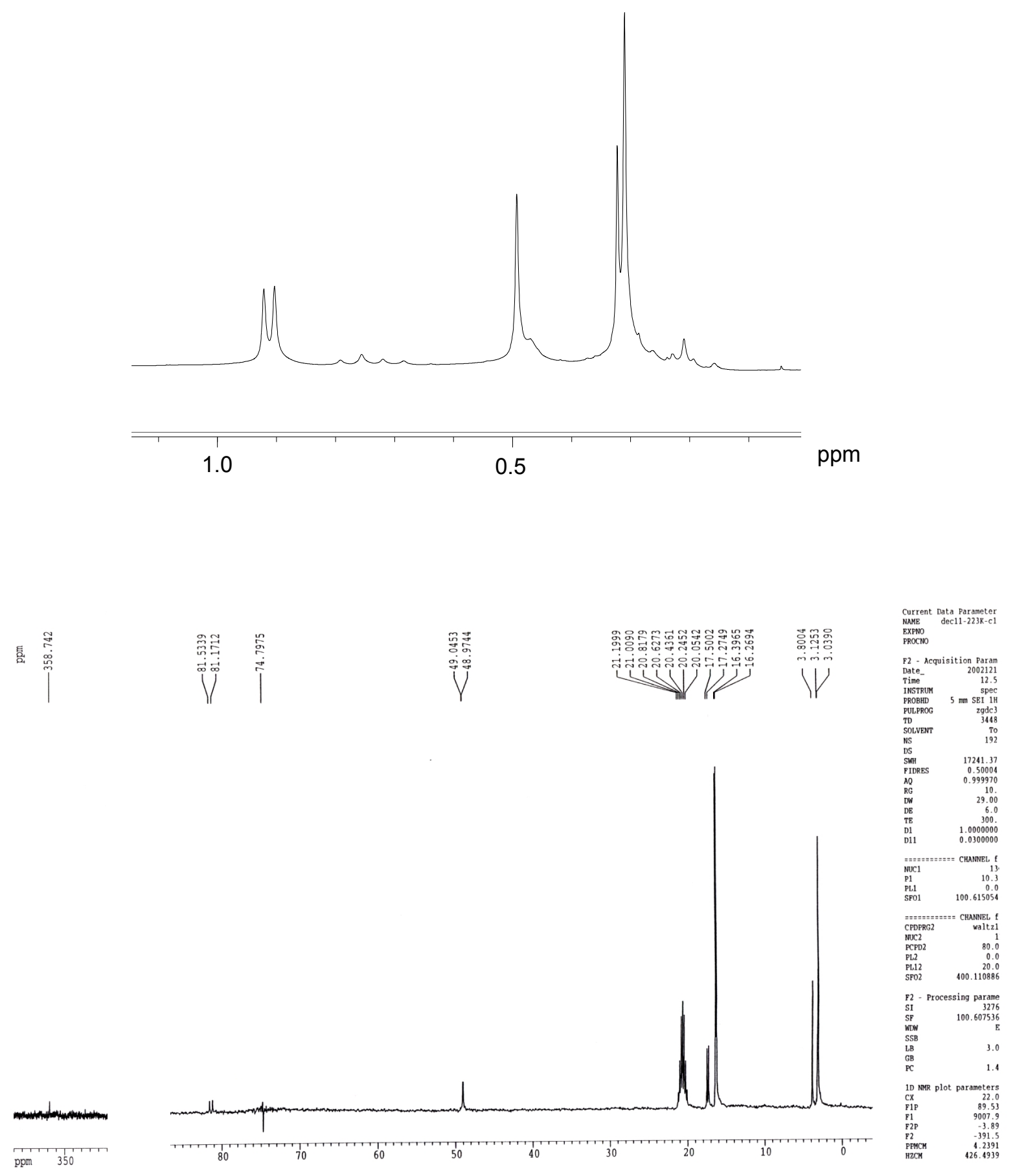

Figure S1. Upper: ${ }^{1} \mathrm{H} \mathrm{NMR}(400.11 \mathrm{MHz})$ spectrum of $\left(\mathrm{Me}_{3} \mathrm{SiCH}_{2}\right)_{3} \mathrm{~W}(\equiv \mathrm{CSiMe})\left(\mathrm{PMe}_{3}\right)(\mathbf{4 a})$ at $-50{ }^{\circ} \mathrm{C}$. Lower: ${ }^{13} \mathrm{C}\left\{{ }^{1} \mathrm{H}\right\}$ NMR $(100.63 \mathrm{MHz})$ spectrum of $4 \mathrm{a}$ at $-50{ }^{\circ} \mathrm{C}$. 

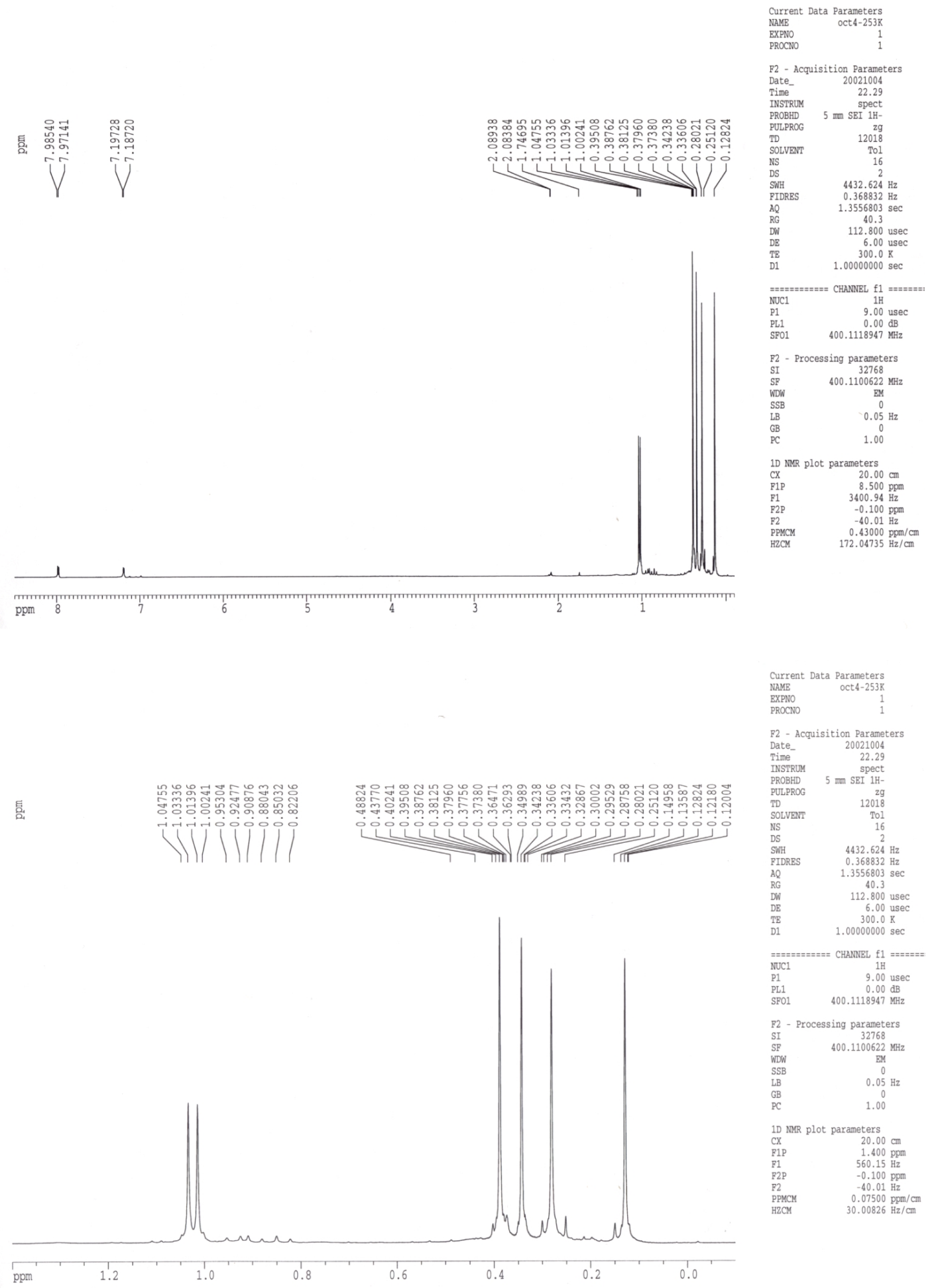

Figure S2. Upper: ${ }^{1} \mathrm{H}$ NMR $(400.11 \mathrm{MHz})$ spectrum of $\left(\mathrm{Me}_{3} \mathrm{SiCH}_{2}\right)_{2} \mathrm{~W}(=\mathrm{CHSiMe})_{2}\left(\mathrm{PMe}_{3}\right)(\mathbf{4 b})$ at $-20^{\circ} \mathrm{C}$. Lower: Expansion of the $-0.1-1.4 \mathrm{ppm}$ region of the spectrum. 

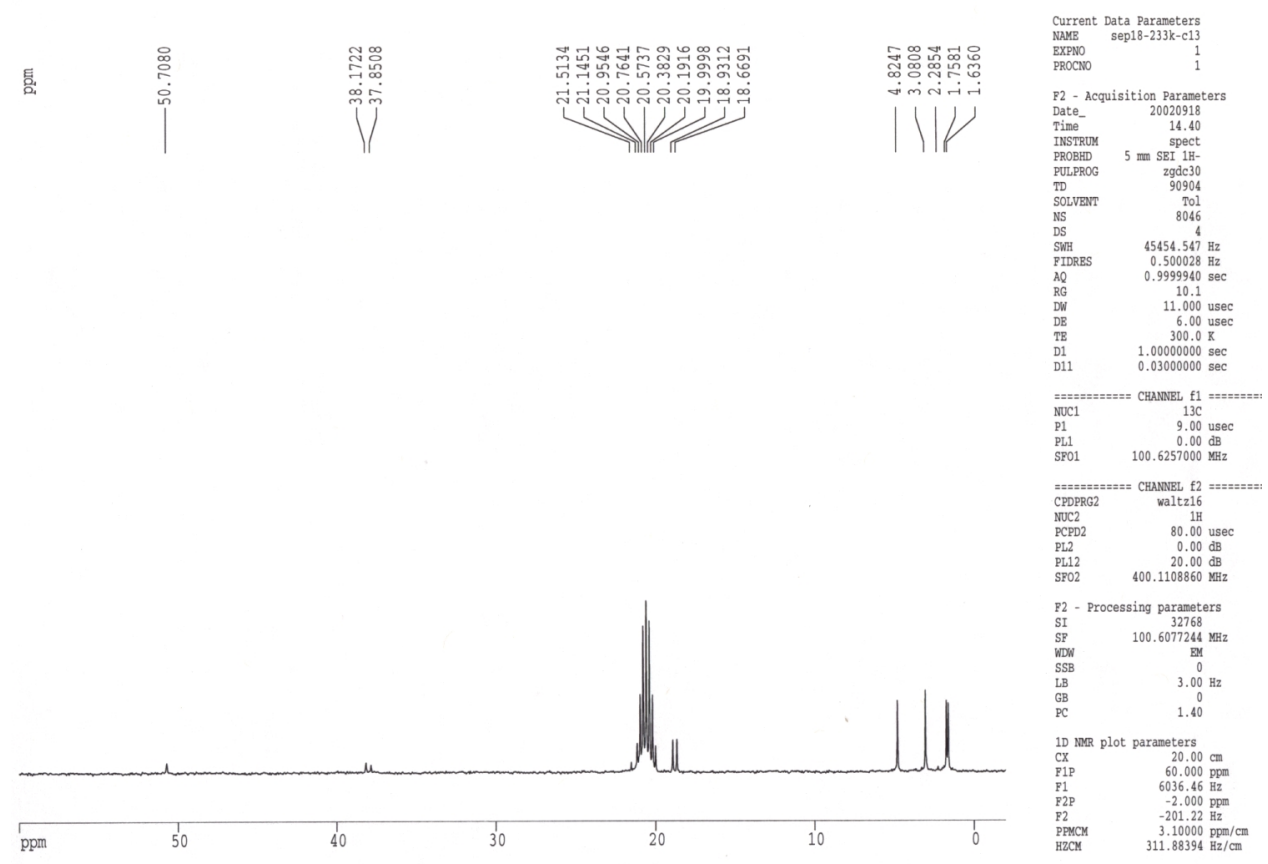

長

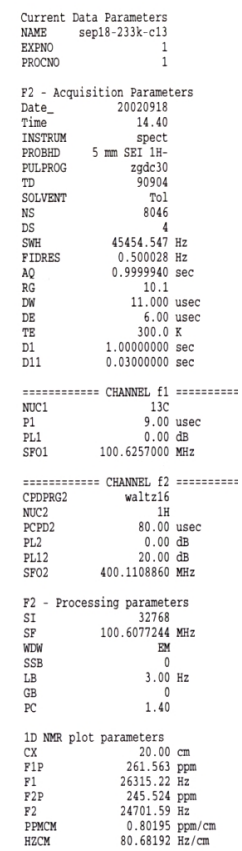

Figure S3. ${ }^{13} \mathrm{C}\left\{{ }^{1} \mathrm{H}\right\}$ NMR $(100.63 \mathrm{MHz})$ spectrum of $\left(\mathrm{Me}_{3} \mathrm{SiCH}_{2}\right)_{2} \mathrm{~W}\left(=\mathrm{CHSiMe}_{3}\right)_{2}\left(\mathrm{PMe}_{3}\right)(\mathbf{4 b})$ at $-40{ }^{\circ} \mathrm{C}$. Upper: $-2-60$ ppm region. Lower: 246-261 ppm region. 

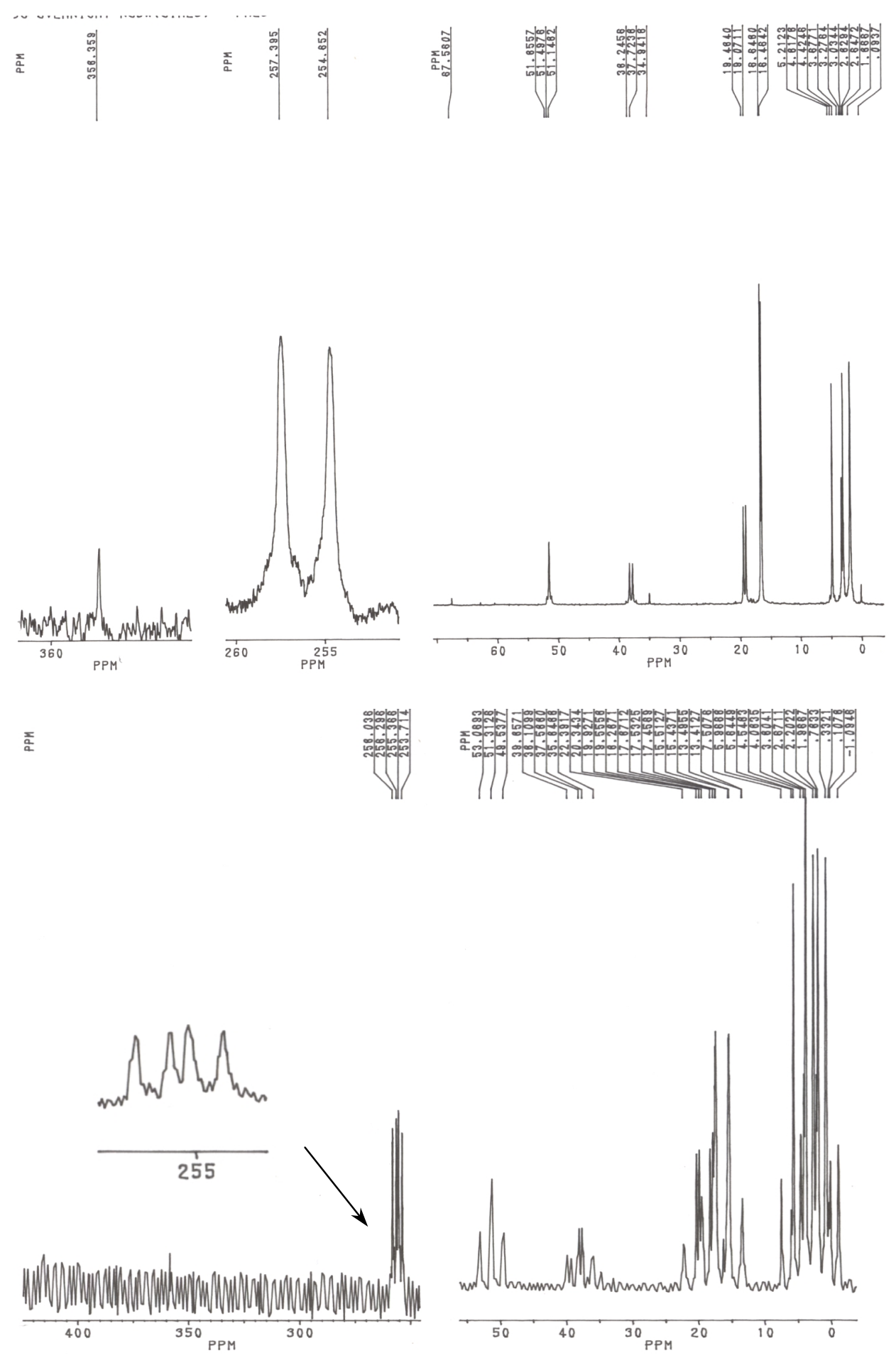

Figure S4. Upper: ${ }^{13} \mathrm{C}\left\{{ }^{1} \mathrm{H}\right\} \operatorname{NMR}(62.896 \mathrm{MHz})$ spectrum of a mixture of $\mathbf{4 a}$ and $\mathbf{4 b}$ at $23{ }^{\circ} \mathrm{C}$. Lower: ${ }^{1} \mathrm{H}$-gated-decoupled ${ }^{13} \mathrm{C}$ NMR $(62.896 \mathrm{MHz})$ spectrum of a mixture of $\mathbf{4 a}$ and $\mathbf{4 b}$ at 23 ${ }^{\circ} \mathrm{C}$. 